Nr 1(70), 2021, s. 147-158

https://doi.org/10.12797/Politeja.18.2021.70.12

\author{
Aleksandra KUMALA (D) \\ Uniwersytet Jagielloński w Krakowie \\ aleksandrae.kumala@doctoral.uj.edu.pl
}

\title{
DUMA, WSTYD, PROFANACJA
}

\section{POSTPAMIĘCIOWY WYMIAR FILMÓW PIĘTNO I PARAGRAF 175}

\section{ABSTRACT Pride, Shame, Profanation. Post-Memory in the Movies Bent and Paragraph 175}

This paper offers a post-memory oriented analysis of the movies Bent (1997) and Paragraph 175 (2000), both referring to the so-called pink triangles-homosexual men persecuted by the Nazis. The author reverses Marianne Hirsch's key concept in order to introduce a new one, "the generation of homosexual post-memory". Theoretical categories of dignity, shame, and profanation are used contextually, to comment on the main themes of the movies and their common interpretations. Seen through the post-memory perspective, films under discussion become substitutes of direct, familial narratives, which for years remained inaccessible due to binding law, social taboos, "institutional homophobia”, and sustained "days of masquerade". Even though it may not seem obvious at first, the text presents that both titles have the potential to activate the process of trauma transfer and create homosexual post-memory as such.

Keywords: homosexual post-memory, paragraph 175, men with the pink triangle

Słowa kluczowe: homoseksualna postpamięć, paragraf 175, więźniowie $\mathrm{z}$ różowym trójkątem 


\section{WSTĘP: POKOLENIE HOMOSEKSUALNEJ POSTPAMIĘCI}

Dorastatem w Niemczech. I nigdy, przenigdy nie styszatem o nazistowskich prześladowaniach homoseksualistów. Nic nie wiedziatem o pokoleniu moich dziadków, moich gejowskich dziadków, choć wychowywatem się w kraju, w którym dwie generacje wstecz byli oni prześladowani i wysytani do obozów koncentracyjnych, a wielu z nich zamordowano. Nic o tym nie wiedziatem. Nie miatem absolutnie żadnej przesztości ${ }^{1}$.

Brak wiedzy o nazistowskich represjach homoseksualistów, których symbolem stał się niesławny paragraf 175 - w niemieckim kodeksie karnym obecny od 1871 do $1994 \mathrm{r}^{2}$ - nie był wyłącznym doświadczeniem cytowanego wyżej Klausa Müllera, badacza losów osób nieheteronormatywnych w czasach III Rzeszy. Jak pokazała ankieta z 1994 r. przeprowadzona na zlecenie Amerykańskiego Kongresu Żydowskiego, tylko połowa dorosłych respondentów z Wielkiej Brytanii i jedna czwarta z USA wiedziała, że wśród ofiar II wojny światowej byli również geje ${ }^{3}$. Na taki stan rzeczy z pewnością wpłynąt fakt, iż pamięć o ofiarach i ich prześladowaniach kształtują m.in. opowieści, indywidualne narracje oraz imiona i twarze znane z ksiązek czy filmów $w^{4}$ - tymczasem pozycja tzw. więźniów z różowym trójkątem ${ }^{5} \mathrm{w}$ dyskursie ofiar II wojny światowej przez długie lata pozostawała marginalna. Na taki stan rzeczy miał wpływ cały szereg czynników: instytucjonalne zagrożenia, społeczne tabu, niedobór świadectw, podwójna niewypowiadalnośc cierpienia, długotrwała niechęć do zbiorowego utożsamienia z tymże cierpieniem i włączenia osób nieheteronormatywnych w krąg dobrego towarzystwa ofiar ${ }^{7}$. Refleksja naukowa poświęcona temu zjawisku niejednokrotnie wymaga dokonywania rozmaitych terminologicznych modyfikacji - jak w przypadku próby wykorzystania pojęcia traumy kulturowej ${ }^{8}$. Choć, wziąwszy pod uwagę podstawowe założenie

Paragraf 175, reż. R. Epstein, J. Friedman, Niemcy, USA, Wielka Brytania 2000. Jeśli nie zaznaczono inaczej, wszystkie przekłady są mojego autorstwa.

2 W 1969 r. przestał obowiązywać na terenie RFN, rok wcześniej - NRD. Z niemieckiego prawodawstwa zniknął ostatecznie w latach 90.

3 K. Müller, INTRODUCTION (Heinz Heger: The Men with the Pink Triangle. Boston 1994), [online] http://kmlink.net/1994/01/introduction-to-heinz-heger-the-men-with-the-pink-triangle/, 20 XI 2020.

4 K. Hammermeister, Inventing History: Toward a Gay Holocaust Literature, „The German Quarterly” 1997, vol. 70, nr 1, s. 19.

5 Symbolem tym oznaczano w obozach koncentracyjnych skazanych na mocy paragrafu 175.

6 Ang. doubly unspeakable - formuła Elizabeth D. Heineman odwołująca się do wojennych doświadczeń, których wypowiadalność ogranicza splot wątków seksualności i nazizmu. Por. E.D. Heineman, Sexuality and Nazism. The Doubly Unspeakable, "Journal of the History of Sexuality” 2002, vol. 11, nr 1-2, s. 22-66.

7 Wspólnota narodowa miata być wspólnotą szlachetnych ofiar - bohaterskich, petnych poświęcenia, krzyw$d z o n y c h$, a istotną rolę w tworzeniu odgrywały motywy cierpienia i ofiary, wraz ze swoją religijna konotacją. K. Stańczak-Wiślicz, Znaleźć się w dobrym towarzystwie ofiar - cierpienie jako element dyskursu legitymizujacego w Polsce po zakończeniu II wojny światowej, [w:] Zapisy cierpienia, red. taż, Wrocław 2011, s. 175, 176.

8 Według Alexandra ma ona miejsce wówczas, gdy cztonkowie zbiorowości czują, że poddani zostali straszliwemu wydarzeniu, pozostawiającemu nieusuwalne ślady na ich grupowej świadomości, na zawsze 
definicyjne Jeffreya C. Alexandra, stała się ona udziałem homoseksualnych ofiar członków tej wspólnoty poddano straszliwemu wydarzeniu, pozostawiającemu nieusuwalne ślady na ich grupowej tożsamości ${ }^{9}$ - w ich przypadku nie doszło ani do konsolidacji grupy, ani do rozszerzenia kregu "my” i uznania cudzego cierpienia za nasze wtasne ${ }^{10}$.

Przeformułowań i dopowiedzeń domaga się również kategoria postpamięci, którą Marianne Hirsch zdefiniowała jako relację taczaca pokolenie biorace udziat $w$ doświadczaniu kulturowej lub kolektywnej traumy z kolejnym, które "pamięta” je wytacznie dzięki opowieściom, obrazom i zachowaniom, wśród których dorastali ${ }^{11}$. Pamięć od postpamięci odróżnia pokoleniowy dystans, od historii - gtęboka osobista więż' $z^{12}$. Charakteryzuje ją dojrzewanie $w$ środowisku zdominowanym przez narracje wywodzace sie sprzed ich narodzin ${ }^{13}$. Choć środowiskiem tym była pierwotnie rodzina, koncepcja obejmować może nie tylko pokolenia potomków ocalałych z Zagłady, ale też jakieś - drugie i/lub trzecie - „pokolenie po” (wielkiej historycznej traumie). Proponuję zatem następujący eksperyment myślowy: potraktowanie cytowanego na wstępie Müllera jako figury reprezentatywnej dla - powołanego do istnienia na potrzeby tego artykułu - „pokolenia homoseksualnej postpamięci”. Odnosiłoby się ono do homoseksualistów urodzonych długo po wojnie i nie tyle przytłoczonych nadmiarem narracji traumatycznych, co całkowicie ich pozbawionych. Rozważam zatem stan rzeczy dla postpamięciowej refleksji wyjątkowy: zamiast dotkliwego nadmiaru wiedzy - jej (równie bolesny) brak; zamiast „głębokiej osobistej więzi” - ewentualność jej wytworzenia dzięki nielicznym, zapośredniczonym przekazom.

Zaaplikowanie postpamięciowego filtru ${ }^{14}$ do odczytania dwóch produkcji o więźniach z różowym trójkątem - filmu Piętno (1997) oraz dokumentu Paragraf 175 (2000) - oznacza spojrzenie na nie jak na szczególnego rodzaju substytuty niedostępnych opowieści rodzinnych, nośniki wiedzy o przeszłości. Obrazy te obdarzone są pewnym postpamięciowym potencjałem: $\mathrm{z}$ jednej strony na różne sposoby konstruują postpamięć, z drugiej - odwołują się do zawartych w tytule artykułu, nierozerwalnie z nią związanych kwestii dumy, wstydu i profanacji.

naznaczajacemu ich wspomnienia oraz zmieniajacemu ich przyszta tożsamość $w$ fundamentalny i nieodwotalny sposób. J.C. Alexander, Trauma kulturowa a tożsamość zbiorowa, [w:] tegoż, Znaczenia spoteczne. Studia z socjologii kulturowej, przeł. S. Burdziej, J. Gądecki, Kraków 2010, s. 195.

9 Tamże.

10 Tamże.

11 M. Hirsch, Pokolenie postpamięci, przeł. M. Borowski, M. Sugiera, „Didaskalia. Gazeta Teatralna” 2011, vol. 18, nr 105, s. 29.

12 M. Hirsch, Żatoba i postpamięć, przeł. K. Bojarska, [w:] Teoria wiedzy o przesztości na tle wspótczesnej humanistyki. Antologia, red. E. Domańska, Poznań 2010, s. 254.

13 Tamże.

14 Sformułowanie to zapożyczam od Jana Burnatowskiego. J. Burnatowski, Postpamięć, afekt, odpowiedzialność. Przypadek Małej Zagłady Anny Janko, „Annales Universitatis Paedagogicae Cracoviensis. Studia Historicolitteraria” 2015, vol. 15, s. 232. 


\section{WYT WARZANIE POSTPAMIĘCI (1): PIĘTNO}

Piętno (1997) w reżyserii Seana Mathiasa jest filmową adaptacją dramatu Martina Shermana. W 1979 r., w momencie publikacji dramatu oraz jego teatralnej premiery, na temat prześladowań homoseksualistów w III Rzeszy wiadomo było niewiele ${ }^{15}$. Również w latach 90. dla przeciętnego odbiorcy kultury popularnej pełnometrażowe Piętno stanowiło pierwszą i w zasadzie jedyną okazję do zetknięcia się z tematem homoseksualnej traumy wojennej. Głównym bohaterem - dramatu i obu jego adaptacji - jest Max: młody gej hedonista. Noc długich noży (1934) zmusza go do ukrywania się wraz z kochankiem, Rudym. Mężczyźni zostają ostatecznie schwytani, a podczas transportu do obozu sadystyczni esesmani dwukrotnie zmuszają Maxa do „wyparcia się” swojej orientacji. Ten z kolei wierzy, że uznanie za heteroseksualnego Żyda i oznaczenie żółtą gwiazdą zwiększy jego szanse na przeżycie ${ }^{16}$. W obozie zakochuje się jednak w innym więźniu - noszącym różowy trójkąt Horście. Długie, monotonne ujęcia pokazują nie tylko ich ciężką pracę; mężczyźni dwukrotnie uprawiają na ekranie seks i doprowadzają się wzajemnie do orgazmu wyłącznie przy użyciu słów. W finałowej scenie, gdy Horst zamiast wykonać rozkaz zdjęcia czapki rzuconej wcześniej na druty - buntuje się i zostaje zastrzelony, protagonista wkłada pasiak nieboszczyka i sam rzuca się na ogrodzenie pod napięciem.

Odbiór Piętna był raczej krytyczny: zarzucano mu bezbarwność i szaroburossić ${ }^{17}$, to znów określano je jako ckliwy, przestylizowany kicz z pornograficznym sznytem ${ }^{18}$. Jeden z publicystów za niedorzecznq uznał wizję obozowego świata, w której dwóch wygtodzonych i wycieńczonych więźniów pod okiem esesmanów odbywa dwu-, trzyminutową rozmowę zakończoną orgazmem. Na poświęconym tytułowi forum w rodzimym serwisie Filmweb.pl zarzut odchodzenia od pewnych reali ${ }^{19}$ spotkat się z odpowiedzią: Ale to wtaśnie nie jest film dokumentalny o holokauście - Osobiście wtaśnie [odbieram] ten film jako historię o geju : ${ }^{20}$. Piotr Kunce stwierdził z kolei, iż pomyst, aby romantyczne zmagania dwóch kolegów z homoseksualizmem umieścić w kontekście mocno znieksztatconego

15 Por. D. Gordon, Playwright Martin Sherman Looks Back at His Landmark Drama Bent, TheaterMania, 4 VIII 2015, [online] https://www.theatermania.com/los-angeles-theater/news/martin-sherman-bent-taper-interview_73724.html, 20 XI 2020.

16 Jak tłumaczył Sherman, motyw ukrywania swojej orientacji i upartego trwania przy wizerunku heteroseksualnego Żyda odzwierciedla wyłącznie wyobrażenie protagonisty o obozowych realiach i panującej tam hierarchii. N. Pfefferman, 'Bent' but not broken, „Jewish Journal” 2015, 1 VI, [online] https:// jewishjournal.com/current_edition/171581/,20 XI 2020.

17 Ch. Hemblade, Bent Review, Empire Online, 1 I 2000, [online] https://www.empireonline.com/movies/bent/review/, 20 XI 2020.

18 S. Holden, Sent From Gay Berlin To Labor at Dachau, „The New York Times” 1997, 26 XI, https:// www.nytimes.com/1997/11/26/movies/film-review-sent-from-gay-berlin-to-labor-at-dachau.html, 20 XI 2020.

19 Film bezptciowy, mato emocjonujacy, odchodzacy od pewnych reali... (5/10), Filmweb [online] https:// www.filmweb.pl/film/Piętno-1997-31929/discussion/Film+bezpłciowy\%2C+mało+emocjonujący $\% 2 \mathrm{C}+$ odchodzący+od+pewnych+reali...+\%285+10\%29,2332819, 20 XI 2020. Pisownia oryginalna.

Tamże. 
obozu koncentracyjnego - jest po prostu koncepcyjnie btędny i czyni ten film kompletnie niewiarygodnym oraz że prawie wszystko jest [w nim - A.K.] fatszywe ${ }^{21}$.

Powyższy - dominujący - schemat recepcji pokazuje, że postpamięciowy potencjał Piętna jako jednego z wariantów (dramat, spektakl teatralny, film) wyobrażeniowej inwestycji, projekcji, kreacji2 ${ }^{22}$ twórców trzeciego pokolenia nie jest oczywisty. Do jego ujawnienia nie dochodzi w sposób automatyczny, niezależnie od dobrej woli lub jej braku; zdolność do uruchomienia postpamięciowych sensów pozostaje w związku z perspektywą, wrażliwością, doświadczeniami odbiorcy. Jednocześnie, uświadamiając zarówno homo-, jak i heteroseksualnej publiczności, że coś takiego jak nazistowskie prześladowania homoseksualistów w ogóle miało miejsce ${ }^{23}$, dzieło może pretendować do miana pierwszego ogólnodostępnego substytutu bezpośredniego przekazu, latami blokowanego przez prawne restrykcje i społeczne tabu otaczające obozową (homo)seksualność. Warunkiem rozpoczęcia międzypokoleniowego transferu traumatycznych doświadczeń jest jednak odwrócenie znanego z Żatoby i postpamięci schematu - przejęcie inicjatywy przez trzecie pokolenie, prowadzące do odzyskania tego, co do tej pory pomijano milczeniem ${ }^{24}$. Piętno traktować można jako produkt ery gejowskiego wyzwolenia (gay liberation) lat 70. XX w., a za jego rzeczywisty temat uznawać wychodzenie z samoopresji (self-oppression) ${ }^{25}$. Ja zwracam uwagę na postpamięciowy aspekt produkcji - jednocześnie konstruowanej przez jakieś „pokolenie po” i dla jakiegoś (homoseksualnego) „pokolenia po” przeznaczonej. Długotrwały proces uświadamiania, konfrontowania $\mathrm{z}$ traumą rozpoczyna więc wprowadzenie jej do dyskursu, a nie - jak w tradycyjnym modelu Hirsch - permanentna, nadmiarowa, uporczywa obecność w nim.

Jako że na przełomie lat dziewięćdziesiątych i pierwszej dekady XXI w. wiedza o nazistowskich prześladowaniach homoseksualistów nie była powszechna, zasadne wydaje się założenie, iż (pop)kulturowe zapośredniczenie - obok pokoleniowego dystansu i gejowskiego aktywizmu - wpłynęło na kształtowanie się homoseksualnej postpamięci. Choć istotą filmów fabularnych nawiązujących treścią do jakiegoś wydarzenia granicznego ${ }^{26}$ jest nie tyle danie bezpośredniego świadectwa, co fikcjonalne przetworzenie,

21 P. Kunce, Bent (Piętno), Forum Kreatywnych Inspiracji, 19 VIII 2014, [online] http://forum-inspiracji.pl/bent-pietno/, 20 XI 2020.

22 A. Mach, Poetyka postpamięci i etyka świadkowania w badaniach Marianne Hirsch, „Humanistyka XXI wieku" 2010, nr 1, s. 107.

Zob. G. Woods, A History of Gay Literature. The Male Tradition, New Haven-London 1998, s. 256.

24 A. Mach, Poetyka postpamięci..., s. 109.

25 Zob. G. Woods, $A$ History..., s. 256.

26 Rozumianego jako takie, które wykracza poza możliwość wyobrażania sobie czy przewidywania. [...] Doświadczenie takie może wcią̇ wystawiać na próbę lub przekraczać wyobraźnię, także tych, którzy nie doświadczyli go bezpośrednio (tych, których tam nie byto). Tutaj fakty zdaja się wykraczać poza wtadze wyobraźni i moga nawet wydawać się niemożliwe - to woda na mtyn negacjonistów czy tych, którzy zaprzeczaja istnieniu owych wydarzeń. D. LaCapra, Studia nad trauma: jej krytycy i powiktane losy, [w:] tegoż, Historia w okresie przejściowym. Doświadczenie, tożsamość, teoria krytyczna, przeł. K. Bojarska, Kraków 2009, s. 172. 
nierzadko o alegorycznym charakterze $e^{27}$, pełne przepychu, burleskowe, niemal pornograficzne sceny gejowskiego życia w Berlinie tuż przed prześladowaniami mogą spełniać podobną funkcję co analizowane przez Hirsch fotografie z Mausa: reprezentować to, czego już nie ma. Przedstawiać jednak także to, co byto i, w tym konkretnym przypadku, zostato brutalnie zniszczone. Przedstawiać także życie, którego już nie ma, ale które na przekór wszystkiemu wciąż trwa ${ }^{28}$.

Dlaczego dostrzeżenie postpamięciowego wydźwięku Piętna wymaga wysiłku? Po pierwsze, poziom umowności wspomnianych scen raczej odbiega od normy ${ }^{29}$ - skutkuje to inwestowaniem całej odbiorczej energii w tropienie błędów, nieścisłości i rzekomych przekłamań. Po wtóre, w przypadku tej grupy ofiar mamy do czynienia ze splotem tematów seksualności i II wojny światowej - wzbudzających ogromne zainteresowanie, a jednocześnie potrafiących wprawić w zakłopotanie ${ }^{30}$, zwłaszcza gdy nie sposób oddzielić sfery cielesności, fizyczności człowieka od sfery niewyrażalności, wzniosłości i sacrum. Parafrazując stanowisko Przemysława Czaplińskiego wyrażone w eseju $\mathrm{Za}$ gtada i profanacje, ujęłabym rzecz następująco: omawiana produkcja przywołuje kategorię postpamięci $w$ sposób nieoczywisty, a zarazem niejasny. Mówi o niej, ale nie tylko o niej i nie przede wszystkim o niej ${ }^{31}$. Na pierwszy plan wysuwają się co najmniej dwa inne wątki.

Max, według Erica Sterlinga, pomimo wyrządzonych sobie i innym krzywd, może umrzé́ z godnością, jako osoba, która naprawdę jest - nie zaśjako oszust ${ }^{32}$. Wyraźny kontrast pomiędzy scenami z pierwszej (sprzed aresztowania) i drugiej (obozowa niewola) części filmu odzwierciedlać ma wewnętrzną przemianę bohatera, a uwznioślona scena samobójczej śmierci - przypieczętowywać proces samoakceptacji. Znaczenie symboliczne zdeponowano także w innej, najbardziej kontrowersyjnej, scenie homoseksualnego stosunku - dochodzi w niej do rozbudzenia seksualności, przez Bożenę Karwowską uznawanego za jedną z obozowych praktyk ocalajacych ${ }^{33}$. W kontekście obozowym seks staje się oznaka ludzkiej godności, zwtaszcza jeśli to wtaśnie tego rodzaju seks sprawit, że Max i Horst w ogóle znaleźli się w niewoli. [...] Odkrywajac swa mitość do Horsta, Max nie tylko odzyska wiare w homoseksualne uczucie, ale zaakceptuje to, czego wypart się na początku: wtasny homoseksualizm ${ }^{34}$.

27 K. Loska, Kino i trauma - utracona tożsamość, [w:] tegoż, Nowy film japoński, Kraków 2013, s. 320.

M. Hirsch, Żatoba i postpamięć..., s. 225.

Kilku więźniów w wagonie transportującym ich do obozu; Max wykonujący co wieczór pompki, by zachować tężyznę fizyczną; kadry częstokroć prezentujące jedynie dwóch głównych bohaterów przy pracy i pilnujących ich strażników.

Zob. A. Hájková, Sexuality and the Holocaust, OUP Blog, 11 VIII 2018, [online] https://blog.oup. com/2018/03/sexuality-holocaust/, 20 XI 2020.

P. Czapliński, Zagtada i profanacje, „Teksty Drugie” 2009, nr 4, s. 202.

E. Sterling, Bent straight: the destruction of self in Martin Sherman's Bent, „Journal European Studies” 2002, vol. 32, nr 127, s. 373.

33 Por. B. Karwowska, Ciato, seksualność, obozy zagtady, Kraków 2009, s. 161.

K. Hammermeister, Inventing History..., s. 24-25. 
Nawet jeżeli gest włączenia tego rodzaju doświadczenia w popularny dyskurs wojenny wciąż bywa odczytywany jako profanacyjny, warto mieć na uwadze korzyści płynące ze $z$ derzenia etyk - pojawienie się na horyzoncie innego cierpienia i skonfrontowanie z nim jako wyzwaniem ${ }^{35}$. Według wykładni Giorgio Agambena sam akt profanacji to coś więcej niż unieważnienie dotychczasowych separacji - to poszukiwanie dla nich nowych zastosowań, nauka igrania $z$ istniejacymi formami rozdziatu ${ }^{36}$. Igrania uzasadnionego tym bardziej, że cierpienie więźniów z różowym trójkątem przez długi czas pozostawało niedostępne $i$ oddzielone $e^{37}$. Ów akt profanacji, podobnie jak danie wyrazu homoseksualnej dumie, stanowią integralną część Piętna.

\section{WYTWARZANIE POSTPAMIĘCI (2): PARAGRAF 175}

Dokument Paragraf 175 (2000) Roba Epsteina i Jeffreya Friedmana także charakteryzuje odwrócenie postpamięciowego schematu. Cytowany we wstępie Klaus Müller pojawia się na ekranie w podwójnej roli: reprezentanta pokolenia pozbawionego dostępu do tak istotnych w koncepcji Hirsch rodzinnych historii, obrazów zapośredniczonych w cudzych wspomnieniach lub z zaobserwowanych $w$ dzieciństwie i wczesnej mtodości zachowañ ${ }^{38}$ oraz strażnika pamięci ${ }^{39}$. Rozmawia z tymi, którzy już kiedyś opowiedzieli swoje historie, ale i z tymi, którzy robią to po raz pierwszy.

Prócz opowieści poszczególnych bohaterów na dokument składają się: współczesne ujęcia Berlina czy pozostałości pierwszego nazistowskiego obozu w okupowanej Alzacji, opatrzone komentarzem narratora materiały archiwalne (zdjęcia, wideo) i źródłowe (cytaty z przemówień, fragmenty zapisów prawnych), odwołujące się do czasów tzw. złotej ery (Golden Age) oraz przejęcia władzy przez Hitlera, rozkwitu nazistowskiej ideologii i początku represji. W zakończeniu reżyserzy także sięgają po typowe dla dokumentu środki wyrazu: czarne plansze $\mathrm{z}$ informacjami o okresie obowiązywania paragrafu, powojennej kryminalizacji ofiar oraz o tym, że do końca XX w. żadna z nich nie została oficjalnie uznana za pokrzywdzoną przez reżim nazistowski; sylwetki wszystkich postaci opatrzone krótkimi, quasi-biograficznymi notkami; zasygnalizowane zostaje również, iż dwóch mężczyzn odmówiło udziału w projekcie ${ }^{40}$.

Ze względu na objętościowe ograniczenia tekstu skupię się na dwóch zaprezentowanych w filmie postaciach. Przykładem ofiary, która dopiero przy tej okazji przerywa milczenie, jest Heinz F. (1905-?) - aresztowany i bez procesu wysłany do KL Dachau,

35 P. Czapliński, Zagtada..., s. 212.

36 G. Agamben, Pochwata profanacji, [w:] tegoż, Profanacje, przeł. M. Kwaterko, Warszawa 2006, s. 110.

37 Tamże, s. 98.

38 A. Kuchta, Meandry pamięci. Między koncepcją Henri Bergsona a wizją postpamięci Marianne Hirsch próba zestawienia, „«Maska». Magazyn antropologiczno-społeczno-kulturowy” 2017, nr 34, s. 149.

39 Por. E. Hoffman, After Such Knowledge. A Meditation on the Aftermath of the Holocaust, London 2004.

40 Jednym z nich był Polak, Teofil Kosiński, bohater książki L. van Dijka Cholernie mocna mitość. Prawdziwa historia Stefena K. i Williego G., przeł. A. Chmielecka, F. Fierek, Kraków 2017. 
po wyjściu na wolność ponownie zatrzymany, więziony i sądzony, następnie przewieziony do obozu w Buchenwaldzie, a po odbyciu kary siłą wcielony do niemieckiej armii.

Klaus Müller: Czy powiedziateś kiedyś bratu albo matce [ojciec już wtedy nie żył A.K.] o tym, co spotkato cię wobozie?

Heinz F.: Nigdy nie rozmawiatem o tym ze swoją mama. Może z ojcem mógtbym, ale...

K.M.: Czemu nie?

H.F.: Wstyd... Moja matka nic o tym nie mówita. Pewnie dlatego, że każdy musi pokornie dźwigać wtasne brzemię.

K.M.: Wstyd? Z jakiego powodu?

H.F.: Masz na myśli moja matkę? Może to z powodu wspótczucia - nie chciata mnie urazić ani sprawić, że będzie mi jeszcze ciężej. Nie ustyszatem od niej ani jednego stowa.

K.M.: Dziś aż trudno uwierzyć, że przeżyteś te wszystkie potworne lata, wróciteś i...

H.F: ...i nie potrafię nikomu o tym opowiedzieć?

K.M.: Tak.

H.F.: To prawda, nigdy z nikim o tym nie rozmawiatem.

K.M.: A chciateś z kimś o tym porozmawiać?

H.F.: Może... Może z moim ojcem...

(Po tych słowach Heinz F. zaczyna płakać i przez moment zasłania twarz trzęsącą się dłonią).

K.M.: A później? Mogteśo tym rozmawiaćz innymi?

H.F.: Nigdy. Nikt nie chciat stuchać. Gdy tylko wymsknęto się cztowiekowi jedno $z$ „tych” stów... (Heinz F. lekceważąco macha ręką). [Styszało się w odpowiedzi] „Dajże spokój z tymi sprawami”, „To już skończone, byto, minęto"11.

Oto kolejna odsłona „wytwarzania” postpamięci - na oczach widzów zainicjowany zostaje proces „odzyskiwania” opowieści bezpośrednich świadków dla międzypokoleniowej wspólnoty pamięci ${ }^{42}$. Fragmentaryczność i niedomówienia zastępują uporządkowaną opowieść wspomnieniową ${ }^{43}$, a zdanie Nikt nie chciat stuchać najdobitniej streszcza pozycję homoseksualnych ofiar w powojennej wspólnocie pamięci. O ile samobójstwo głównego bohatera Piętna ma symbolizować jego moralne zwycięstwo nad oprawcami i zakończoną sukcesem walkę z samym sobą, widzów zaś - nierzadko po raz pierwszy skonfrontowanych z tematem - pokrzepiać, o tyle w Paragrafie $175 \mathrm{rzecz}$ wygląda zgoła inaczej. Owszem, niektórzy bohaterowie kwestie seksualności poruszają otwarcie, bez skrępowania czy zażenowania. Znacznie istotniejsze w kontekście postpamięciowego potencjału wydają się jednak wątki skrajnie traumatyczne, m.in. opowieść o okolicznościach utraty pierwszej miłości (młodzieńca zamordowanego wraz

41 Paragraf $175 .$.

42 A. Mach, Poetyka postpamięci..., s. 107.

43 A. Kuchta, Zawtaszczone narracje. Obrazy postpamięci w zbiorze Oskarżam Auschwitz. Opowieści rodzinne Mikotaja Grynberga, „Konteksty Kultury” 2015, vol. 12, nr 2, s. 261. 
z rodzicami w obozie zagłady), anegdota o „śpiewającym lesie” ${ }^{\text {4 }}$ czy tyrada drugiego z interesujących mnie bohaterów, Pierre’a Seela (1923-2005): Teraz rozumiesz, dlaczego milczatem przez czterdzieści lat? Od czasów wojny mam orzeczone dziewięćdziesięcioprocentowe kalectwo. Moja dupa wciaż krwawi! Do dziś! Naziści wpychali mi kawat drewna dtugości dwudziestu pięciu centymetrów w tytek! Myślisz, że potrafie o tym ot tak opowiadać?! Że to dla mnie dobre?! To zbyt wiele jak na moje nerwy, Klaus! Nie moge już tego robić. Wstyd mi za ludzkość. Jestem zażenowany ${ }^{45}$.

Ciężar dotychczas nieobecnej wiedzy o wydarzeniach z przeszłości daje się tu - za sprawą bezpośredniości i emocjonalności przekazu - odczuć o wiele intensywniej niż w przypadku pełnego umowności Piętna. Wypowiedź Seela wprost odnosi się do kolejnego aspektu homoseksualnej postpamięci: okrutnych mechanizmów i długotrwałych skutków wojennej przemocy seksualnej, której nadrzędnym celem pozostaje naznaczenie ofiar - wykorzystanie i ukaranie, czy to poprzez akt seksualny, czy dziatanie seksualizujące, czyli sytuację, gdy sprawca nie wymusza stosunku seksualnego, ale ewidentnie odwotuje się do seksualności swojej ofiary, znęcając się nad nia, wykorzystujac jej ciato, tożsamość seksualna oraz gender ${ }^{46}$.

Wypowiedź Seela robi tym większe wrażenie, że poprzedza rozmowę z Heinzem F. Prezentowane przez mężczyzn postawy diametralnie się różnią: Francuz swój wstyd kieruje na zewnątrz, ku oprawcom, ale i tym wszystkim, którzy doznanych krzywd nie uznawali, deprecjonowali je. Niemiec mówi o wstydzie w kontekście samotności, niezrozumienia i przymusu milczenia; odnosi się do wstydu swojej matki, ale i tego, który zinternalizowa ${ }^{47}$. Zarówno wstyd, jak i upokorzenie mogą być uznawane za pewien rodzaj pamięci - jej psychologiczny odpowiednik to, według Krzysztofa Szwajcy, zjawisko tzw. zwierciadła: patrzenie na siebie oczyma bliskich ${ }^{48}$ (vide: milcząca pani F.). Pamięć - analogicznie: postpamięć - dotycząca traumatycznego okresu nierozerwalnie wiąże się tu z wizją siebie samego jako istoty pogardzanej, lżonej, poddawanej torturom psychicznym i fizycznym, jako niecztowieka, zwierzecia ${ }^{49}$.

44 Eufemizm odnoszący się do stosowanej w obozach kary tzw. słupka. Do dziś mam przez to gęsia skórkę. Wycie i krzyki byty nieludzkie. „Śpiewajacy las”... Tego nie da się wyttumaczyć. To wykracza poza możliwości ludzkiej percepcji. Wiele pozostaje niewypowiedziane - podsumowuje jeden z bohaterów, Heinz Dörmer. Paragraf $175 \ldots$

45 Tamże.

46 J. Ostrowska, Przemilczane. Seksualna praca przymusowa w czasie II wojny światowej, Warszawa 2018, s. 28.

47 Chip Crews zwrócił uwagę, iż choć sędziwy wiek bohatera (wówczas dziewięćdziesięciodwuletniego) sugerowałby, że okres wstydliwości ma on już za sobą (seemingly past the age of shame), Heinz F. nie zdecydowal się na ujawnienie pełnego nazwiska. Ch. Crews, 'Paragraph 175': The Nazis' Victims of Shame, „The Washington Post” 2000, 19 X, [online] https://www.washingtonpost.com/archive/lifestyle/2000/10/19/paragraph-175-the-nazis-victims-of-shame/417b95da-70b4-4c99-8adf-27ff441 $4 \mathrm{c} 24 \mathrm{e} /$ ?noredirect $=$ on\&utm_term=.5e31651 fac7a, 20 XI 2020.

48 K. Szwajca, Ocaleni z Holocaustu w oczach psychiatry, czyli o milczeniu i pamięci, [w:] Pamięć Shoah. Kulturowe reprezentacje i praktyki upamiętnienia, red. T. Majewski, A. Zeidler-Janiszewska, współpr. red. M. Wójcik, Łódź 2011, s. 594. 
Odpowiednikiem sytuacji żydowskich ocalałych, dla których „życie na aryjskich papierach", w ukryciu, życie nieautentyczne trwato dalej w najbardziej intymnej przestrzeni domu ${ }^{50}$, był w przypadku osób nieheteronormatywnych przedłużający się ze względu na zinstytucjonalizowana homofobie $e^{51}$ i społeczne tabu czas maskowani $a^{52}$ - przymusowego zatajania nie tylko swojej orientacji czy tożsamości, ale też szczegółów wojennych traum i przyczyn prześladowań. Homoseksualna postpamięć pozostaje zjawiskiem tyleż nieoczywistym, co rozległym - obejmuje okres o wiele dłuższy niż lata 1939-1945; zawiera w sobie nie tylko doświadczenia prześladowań i przemocy (psychicznej, fizycznej, seksualnej, symbolicznej), lecz także permanentnego niezrozumienia i powojennego wykluczenia.

\section{POTRZEBA EKSPERYMENTU}

Eksperymentalne zaaplikowanie koncepcji postpamięci do analizy dwóch filmów powstałych na przełomie wieków - kiedy to spoglądaniu w (nierzadko problematyczną) przeszłość towarzyszyła chęć zdefiniowania wtasnego miejsca ${ }^{53}$ względem niej - i dotyczących ofiar paragrafu 175, stworzyło możliwość potraktowania tych dzieł jako powotujących ja [tę postpamięć - A.K.] do istnienia ${ }^{54}$, niejako w zastępstwie bezpośrednich relacji, których przepływ ograniczało wiele omówionych w artykule czynników.

Postpamięć nie tylko może, ale niekiedy wręcz musi, wykraczać poza rodzinne kręgi, obejmować dalszych, adaptowalnych świadków ${ }^{55}$. Przypadek Klausa Müllera - homoseksualisty, któremu doskwierała świadomość całkowitego odcięcia od historii i traumy gejowskich dziadków - pozwala wyobrazić sobie proces wytwarzania nieobecnej, homoseksualnej postpamięci przy użyciu zapośredniczonych przekazów. Postpamięciowego potencjału Piętna i Paragrafu 175 upatrywałabym w podejmowanej przez nie - i, jeśli mowa o produkcjach filmowych, głównie przez nie ${ }^{56}$ - próbie rozpoznania i przyswojenia wydarzeñ ${ }^{57}$ nieprzyswajalnych dla praprzodków. $Z$ tej perspektywy twórcy omówionych dzieł jawią się jako nieliczni, którzy zabrali głos w imieniu homoseksualnych prześladowanych, zamiast nich, ale także i przeciw nim - przeciw ich milczeniu ${ }^{58}$. Nawet dziś, 20 lat po premierze obu tytułów, tego rodzaju gesty nie należą do powszechnych.

\section{Tamże, s. 593.}

51 J. Steakley, Homosexuals \& the Holocaust: Homosexuals \& the Third Reich, Jewish Virtual Library, [online] https://www.jewishvirtuallibrary.org/homosexuals-and-the-third-reich, 20 XI 2020.

Por. C. Schoppmann, Czas maskowania. O sytuacji kobiet w narodowym socjalizmie, przeł. J. Ostrowska, „Teksty Drugie” 2008, nr 5, s. 163-173.

M. Hirsch, Pokolenie postpamięci..., s. 29.

54 Tamże.

55 Tamże.

56 Warto też zwrócić uwagę na dokument Martwi geje i żywe lesbijki (2007) Rosy von Praunheim czy fabułę Un amour à taire (2005) Christiana Faure.

57 A. Mach, Poetyka postpamięci..., s. 107.

58

Tamże. 


\section{BIBLIOGRAFIA}

Agamben G., Pochwata profanacji, [w:] tegoż, Profanacje, przeł. M. Kwaterko, Warszawa 2006. Alexander J.C., Trauma kulturowa a tożsamość zbiorowa, [w:] tegoż, Znaczenia spoteczne. Studia z socjologii kulturowej, przeł. S. Burdziej, J. Gądecki, Kraków 2010, s. 195-221.

Burnatowski J., Postpamięć, afekt, odpowiedzialność. Przypadek Małej Zagłady Anny Janko, „Annales Universitatis Paedagogicae Cracoviensis. Studia Historicolitteraria” 2015, vol. 15, https://doi.org/10.24917/3940.

CrewsCh., 'Paragraph 175':The Nazis'VictimsofShame, ,The Washington Post”2000, 19X, [online] https://www.washingtonpost.com/archive/lifestyle/2000/10/19/paragraph-175-thenazis-victims-of-shame/417b95da-70b4-4c99-8adf-27ff4414c24e/?noredirect=on\&utm_ term $=.5$ e31651 fac7a.

Czapliński P., Zagtada i profanacje, „Teksty Drugie” 2009, nr 4.

Film bezptciowy, mato emocjonujacy, odchodzacy od pewnych reali... (5/10), Filmweb, [online] https://www.filmweb.pl/film/Piętno-1997-31929/discussion/Film+bezpłciowy\%2C+ma ło+emocjonujący\%2C+odchodzący+od+pewnych+reali...+\%285+10\%29,2332819.

Gordon D., Playwright Martin Sherman Looks Back at His Landmark Drama Bent, TheaterMania, 4 VIII 2015, [online] https://www.theatermania.com/los-angeles-theater/news/ martin-sherman-bent-taper-interview_73724.html.

Hájková A., Sexuality and the Holocaust, OUP Blog, 11 VIII 2018, [online] https://blog.oup. com/2018/03/sexuality-holocaust/.

Hammermeister K., Inventing History: Toward a Gay Holocaust Literature, „The German Quarterly" 1997, vol. 70, nr 1, s. 18-26, https://doi.org/10.2307/407838.

Heineman E.D., Sexuality and Nazism. The Doubly Unspeakable, ,Journal of the History of Sexuality" 2002, vol. 11, nr 1-2, s. 22-66.

Hemblade Ch., Bent Review, Empire Online, 1 I 2000, [online] https://www.empireonline. $\mathrm{com} / \mathrm{movies} /$ bent/review/.

Hirsch M., Pokolenie postpamięci, przeł. M. Borowski, M. Sugiera, „Didaskalia. Gazeta Teatralna" 2011, vol. 18, nr 105..

Hirsch M., Żatoba i postpamięć, przeł. K. Bojarska, [w:] Teoria wiedzy o przesztości na tle wspótczesnej humanistyki. Antologia, red. E. Domańska, Poznań 2010.

Hoffman E., After Such Knowledge. A Meditation on the Aftermath of the Holocaust, London 2004.

Holden S., Sent from Gay Berlin to Labor at Dachau, „The New York Times” 1997, 26 XI, [online] https://www.nytimes.com/1997/11/26/movies/film-review-sent-from-gay-berlin-tolabor-at-dachau.html.

Karwowska B., Ciato, seksualność, obozy zagtady, Kraków 2009.

Kuchta A., Meandry pamięci. Między koncepcja Henri Bergsona a wizja postpamięci Marianne Hirsch - próba zestawienia, „ «Maska». Magazyn antropologiczno-społeczno-kulturowy” 2017, nr 34 .

Kuchta A., Zawtaszczone narracje. Obrazy postpamięci w zbiorze Oskarżam Auschwitz. Opowieści rodzinne Mikotaja Grynberga, „Konteksty Kultury” 2015, vol. 12, nr 2, https://doi.org/ 10.4467/23531991KK.15.016.3712. 
Kunce P., Bent (Piętno), Forum Kreatywnych Inspiracji, 19 VIII 2014, [online] http://forum-inspiracji.pl/bent-pietno/.

LaCapra D., Studia nad trauma: jej krytycy i powiktane losy, [w:] tegoż, Historia w okresie przejściowym. Doświadczenie, tożsamość, teoria krytyczna, przeł. K. Bojarska, Kraków 2009.

Loska K., Kino i trauma - utracona tożsamość, [w:] tegoż, Nowy film japoński, Kraków 2013.

Mach A., Poetyka postpamięci i etyka świadkowania w badaniach Marianne Hirsch, „Humanistyka XXI wieku" 2010, nr 1.

Müller K., INTRODUCTION (Heinz Heger: The Men with the Pink Triangle. Boston 1994), [online] http://kmlink.net/1994/01/introduction-to-heinz-heger-the-men-with-the-pinktriangle/, 20 XI 2020.

Ostrowska J., Przemilczane. Seksualna praca przymusowa w czasie II wojny światowej, Warszawa 2018.

Paragraf 175, reż. R. Epstein, J. Friedman, Niemcy, USA, Wielka Brytania 1997.

Pfefferman N., 'Bent' but not broken, „Jewish Journal” 2015, 1 VI, [online] https://jewishjournal.com/current_edition/171581/.

Piętno, reż. S. Mathias, Japonia, Wielka Brytania 1997.

Schoppmann C., Czas maskowania. O sytuacji kobiet w narodowym socjalizmie, przeł. J. Ostrowska, „Teksty Drugie” 2008, nr 5.

Stańczak-Wiślicz K., Znaleźć się w dobrym towarzystwie ofiar - cierpienie jako element dyskursu legitymizującego w Polsce po zakończeniu II wojny światowej, [w:] Zapisy cierpienia, red. K. Stańczak-Wiślicz, Wrocław 2011, s. 167-177.

Steakley J., Homosexuals \& the Holocaust: Homosexuals \& the Third Reich, Jewish Virtual Library, [online] https://www.jewishvirtuallibrary.org/homosexuals-and-the-third-reich.

Sterling E., Bent straight: the destruction of self in Martin Sherman's Bent, „Journal of European Studies” 2002, vol. 32, nr 127, https://doi.org/10.1177\%2F004724410203212703.

Szwajca K., Ocaleni z Holocaustu w oczach psychiatry, czyli o milczeniu i pamięci, [w:] Pamięć Shoah. Kulturowe reprezentacje i praktyki upamiętnienia, red. T. Majewski, A. Zeidler-Janiszewska, wspołpr. red. M. Wójcik, Łódź 2011.

Van Dijk L., Cholernie mocna mitość. Prawdziwa historia Stefena K. i Williego G., przeł. A. Chmielecka, F. Fierek, Kraków 2017.

Woods G., A History of Gay Literature. The Male Tradition, New Haven-London 1998.

Aleksandra KUMALA - kulturoznawczyni, doktorantka UJ. Współredaktorka tomu In(ter)wencje. Analizy kulturoznawcze. Laureatka XXV edycji Konkursu im. J.J. Lipskiego. W pracy naukowej bada problematykę pamięci i reprezentacji homoseksualnych relacji w obozach koncentracyjnych. Jej zainteresowania badawcze ogniskują się także wokół zagadnień współczesnej popkultury. 